\title{
Copper Chloro-Complexes Concentrated Solutions: An Electrochemical Study
}

\author{
Giampaolo Lacarbonara ${ }^{1}$, Luigi Faggiano ${ }^{1}$, Stefania Porcu ${ }^{2}$, Pier Carlo Ricci ${ }^{2}$, Stefania Rapino ${ }^{1}$, \\ Declan P. Casey ${ }^{3}$, James F. Rohan ${ }^{3}$ (D) and Catia Arbizzani ${ }^{1, *}$ (i)
}

1 Department of Chemistry "Giacomo Ciamician", Alma Mater Studiorum-University of Bologna, Via F. Selmi 2, 40126 Bologna, Italy; giampaol.lacarbonar2@unibo.it (G.L.); luigi.faggiano3@unibo.it (L.F.); stefania.rapino3@unibo.it (S.R.)

2 Department of Physics, University of Cagliari, SP 8 Km 0.700, 09042 Cagliari, Italy; stefania.porcu@unica.it (S.P.); carlo.ricci@unica.it (P.C.R.)

3 Tyndall National Institute, Lee Maltings, University College Cork, T12R5CP Cork, Ireland; declan.casey@tyndall.ie (D.P.C.); james.rohan@tyndall.ie (J.F.R.)

* Correspondence: catia.arbizzani@unibo.it

Citation: Lacarbonara, G.; Faggiano, L.; Porcu, S.; Ricci, P.C.; Rapino, S.;

Casey, D.P.; Rohan, J.F.; Arbizzani, C. Copper Chloro-Complexes Concentrated Solutions: An Electrochemical Study. Batteries 2021, 7, 83. https://doi.org/10.3390/ batteries7040083

Academic Editor: Elton J. Cairns

Received: 25 September 2021

Accepted: 1 December 2021

Published: 3 December 2021

Publisher's Note: MDPI stays neutral with regard to jurisdictional claims in published maps and institutional affiliations.

Copyright: ( $\odot 2021$ by the authors Licensee MDPI, Basel, Switzerland. This article is an open access article distributed under the terms and conditions of the Creative Commons Attribution (CC BY) license (https:// creativecommons.org/licenses/by/ $4.0 /)$.

\begin{abstract}
Basic studies on concentrated solutions are becoming more and more important due to the practical industrial and geological applications. The use in redox flow batteries is one of the most important applications of these solutions. Specifically, in this paper we investigated highconcentrated copper chloro-complexes solutions with different additives. The concentration of ligands and additives affects the physicochemical and electrochemical properties of $2 \mathrm{M}$ solutions of $\mathrm{Cu}(\mathrm{I})$ and $\mathrm{Cu}(\mathrm{II})$. Solutions with calcium chloride and $\mathrm{HCl}$ as $\mathrm{Cl}^{-}$source were investigated with $\mathrm{Cu}: \mathrm{Cl}$ ratios of 1:5 and 1:7, the 1:5 $\mathrm{Cu}: \mathrm{Cl}$ ratio being the best performing. The substitution of calcium chloride with ammonium chloride increased the conductivity. However, while the effect on the positive electrode process was not very evident, the reversibility of the copper depositionstripping process was greatly improved. Orthophosphoric acid could be a viable additive to decrease the complexation of calcium with chloride anions and to improve the stability of $\mathrm{Cu}$ (II) chlorocomplexes. Absorption spectroscopy demonstrated that phosphate ions do not coordinate copper(II) but lead to a shift in the distribution of copper chloro-complexes toward more coordinated species. Electrochemically, the increased availability of chloride anions in solution stabilized the $\mathrm{Cu}(\mathrm{II})$-rich solution and led to increased reversibility of the $\mathrm{Cu}(\mathrm{II}) / \mathrm{Cu}(\mathrm{I})$ redox process.
\end{abstract}

Keywords: copper; chloro complexes; redox flow batteries (RFB); CuRFB

\section{Introduction}

The interest in copper chloro-complexes is not new. $\mathrm{CuCl}$ solutions have enabled a more economical electrowinning process than $\mathrm{CuSO}_{4}$ solutions, given that in $\mathrm{CuCl}$ electrolytes a one-electron process occurs at a lower potential [1]. In addition, concentrated brines have a role in geological field studies [2-4]. The application in alternative hydrometallurgic processes [5,6] has maintained a high interest in copper complexes. In the field of energy storage, several groups have actively pursued the development of thermochemical cycles for hydrogen production based on the $\mathrm{Cu}-\mathrm{Cl}$ cycle in which the hydrogen is produced by the electrochemical reaction of the $\mathrm{CuCl} / \mathrm{HCl}(\mathrm{aq})$ electrolyzer [7-10]. In addition, thermally regenerative ammonia batteries that convert low-grade waste heat into electrical power can use ligands to stabilize $\mathrm{Cu}(\mathrm{I})$ ions in the anolyte and catholyte chambers, achieving coulombic efficiencies above $90 \%$ [11].

In the field of batteries, the application of copper-complex chemistry was exploited for the first time in the mid-seventies $[12,13]$. In the last decade, there has been a renewed interest in copper-based batteries, specifically copper redox flow batteries (CuRFBs). The research, indeed, has been focused on different kinds of CuRFB, from thermally regeneration, based on the complexation of $\mathrm{Cu}^{+}$with acetonitrile [14], to those operating with 
deep eutectic solvents [15] or with highly concentrated chloride [16,17] or bromide [18] solutions. CuRFBs are more sustainable than redox flow batteries based on vanadium, for stationary application and for coupling with renewable energy sources. Within the variety of RFB that has been proposed since the seventies [19], vanadium based redox flow batteries (VRFB) have been the most studied and commercialized. However, the VRFB system employs toxic and high-cost materials, the latter including perfluorinated membranes as separators [20,21]. On the contrary, copper RFB can take advantage of the lower cost of copper with respect to that of vanadium, of the possibility of using other membranes than perfluorinated ones, and of the well-consolidated value chain in Europe of copper with respect to vanadium.

Copper halide-complexes play a crucial role in developing a highly performing CuRFB system. Specifically, their solubility and diffusion coefficients are of paramount importance in these systems. Copper bromo- and chloro-complexes have been investigated and the thermodynamic and kinetics parameters evaluated from dilute and concentrated copper solutions [22-29]. Stability constants were also evaluated in dilute solutions of copper chloride complexes [25]. It was found that in the presence of a high concentration of halides, $\mathrm{Cu}^{+}$and $\mathrm{Cu}^{2+}$ form halide-complexes with increasing halide content by increasing the number of halide ligands, up to $\mathrm{CuX}_{3}{ }^{2-}$ and $\mathrm{CuX}_{4}{ }^{2-}$ in complexes for $\mathrm{Cu}(\mathrm{I})$ and $\mathrm{Cu}(\mathrm{II})$, respectively $[25,26]$. The diffusion coefficients of $\mathrm{Cu}^{+}$and $\mathrm{Cu}^{2+}$ range from $10^{-5}$ to $10^{-6} \mathrm{~cm}^{2} \mathrm{~s}^{-1}$, with higher values for higher temperatures and for $\mathrm{Cu}^{+}$than for $\mathrm{Cu}^{2+}$, with a small variation for different $\mathrm{X}^{-}$concentration [26].

However, the increase of the copper concentration, needed to achieve high energy $\mathrm{RFB}$, brings a tremendous increase in the ionic strength of the solution needed to maintain a suitable copper-to-halide ratio. In these conditions, the interactions between ions are more intense, and the decrease of water activity strongly affects physicochemical parameters like viscosity and density, as well as conductivity and the diffusion coefficient. Several studies have been carried out in concentrated solutions of copper halides in electrolyzer technology for hydrogen production to evaluate the thermodynamic parameters [8,9,27-29]. The diffusion coefficients of $\mathrm{Cu}$ (II) chlorocomplexes at $40{ }^{\circ} \mathrm{C}$ in $2 \mathrm{M} \mathrm{CuCl}_{2}$ solutions were found to be in the range $10^{-5}$ to $10^{-7} \mathrm{~cm}^{2} \mathrm{~s}^{-1}$ depending on the solution composition [16,30-32]. The lowest values were achieved with an increase of $\mathrm{Cl}^{-}$concentration by changing the $\mathrm{Cl}^{-}$source from $\mathrm{HCl}$ to $\mathrm{CaCl}_{2}$ while maintaining the $\mathrm{Cu}: \mathrm{Cl}$ ratio constant [30].

In order to achieve RFB technology with high performance and cycle life, the total concentration of copper and chloride in the electrolytes must be considered. Sanz et al. [16] demonstrated that a $\mathrm{Cu}: \mathrm{Cl}$ ratio of 1:5 is mandatory to ensure salt solubility and cuprous cation stability by $\mathrm{Cl}$-complexation. The choice of the chloride sources as supporting electrolytes influences the physical properties of the copper-chloride electrolytes and the electrochemical properties of the $\mathrm{Cu}(\mathrm{II}) / \mathrm{Cu}(\mathrm{I})$ redox couple. The use of $\mathrm{HCl}$ or $\mathrm{CaCl}_{2}$ alone as supporting electrolyte limits the minimum temperature and the electrolyte concentration at which the solution does not show precipitates. On the contrary, solutions containing both $\mathrm{HCl}$ and $\mathrm{CaCl}_{2}$ are stable without precipitates over a wide range of temperatures, from 5 to $70{ }^{\circ} \mathrm{C}$, affording their practical application in the CuRFB $[16,17,30]$.

The aim of this study was to investigate copper concentrated solutions of interest for CuRFB in order to optimize cell performance. We report and discuss the results of the physicochemical and electrochemical characterization of $2 \mathrm{M}$ solutions of $\mathrm{Cu}(\mathrm{I})$ and $\mathrm{Cu}(\mathrm{II})$ with copper to chloride ratios of 1:5 and 1:7, where the concentration and the counter-ion of the chloride complexing agent are varied. The cell operating temperature was maintained between $40{ }^{\circ} \mathrm{C}$ and $60^{\circ} \mathrm{C}$ to reproduce the real operating conditions of RFB, where low temperatures are preferable to reduce system heating costs. The low temperature range requires that the state of charge $(\mathrm{SoC})$ never exceeds $90 \%$ to avoid $\mathrm{CuCl}_{2}$ precipitation. In addition, in concentrated $\mathrm{CuCl}$ solutions the $\mathrm{pH}$ must be controlled to allow for total solubilization of the salt. For this reason, the $\mathrm{HCl}$ concentration was maintained at $6 \mathrm{M}$. 


\section{Results and Discussion}

\subsection{Solutions with Calcium Chloride}

Solutions with only $\mathrm{CuCl}$ or $\mathrm{CuCl}_{2}$ as copper salt, and solutions with copper concentration shared between $\mathrm{CuCl}$ and $\mathrm{CuCl}_{2}$ to simulate the $0 \%, 100 \%$, and $50 \% \mathrm{SoC}$, with $\mathrm{Cu}: \mathrm{Cl}$ ratios 1:5 and 1:7, were selected and analyzed with a view to CuRFB technology. While physicochemical parameters have an impact on the energy consumption of the CuRFB hydraulic system, electrochemical properties are fundamental in determining the reaction kinetics and overall battery performance.

Table 1 summarize the composition of the solutions 1-6 (from here on indicated with a number) containing $\mathrm{CaCl}_{2}$, the conductivity, the viscosity, and the density at $40{ }^{\circ} \mathrm{C}$, while Figure 1 shows the above parameters at different temperatures.

Table 1. Physicochemical properties at $40{ }^{\circ} \mathrm{C}$ of copper electrolytes with different concentrations of copper and calcium chloride with $\mathrm{Cu}: \mathrm{Cl}$ ratios of 1:5 and 1:7. The relative errors of conductivity, viscosity, and density measurements are $0.5 \%, 0.35 \%$, and $0.1 \%$, respectively.

\begin{tabular}{|c|c|c|c|c|c|c|c|c|}
\hline$n$ & $\begin{array}{c}\mathrm{CuCl}_{2} \\
\mathrm{M}\end{array}$ & $\begin{array}{c}\mathrm{CuCl} \\
\mathrm{M}\end{array}$ & $\begin{array}{c}\mathrm{CaCl}_{2} \\
\mathrm{M}\end{array}$ & $\begin{array}{c}\mathrm{HCl} \\
\mathbf{M}\end{array}$ & $\mathrm{Cu}: \mathrm{Cl}$ & $\begin{array}{c}\sigma \\
\mathrm{mS} \mathrm{cm}\end{array}$ & $\begin{array}{c}\eta \\
\mathrm{mPa} s\end{array}$ & $\begin{array}{c}\rho \\
\operatorname{kg~m}^{-3}\end{array}$ \\
\hline 1 & / & 2 & 1 & 6 & $1: 5$ & 634 & 1.41 & 1312 \\
\hline 2 & 1 & 1 & 0.5 & 6 & $1: 5$ & 605 & 1.78 & 1291 \\
\hline 3 & 2 & / & / & 6 & $1: 5$ & 645 & 1.38 & 1308 \\
\hline 4 & / & 2 & 3 & 6 & $1: 7$ & 364 & 2.80 & 1442 \\
\hline 5 & 1 & 1 & 2.5 & 6 & $1: 7$ & 359 & 2.93 & 1431 \\
\hline 6 & 2 & / & 2 & 6 & $1: 7$ & 417 & 2.10 & 1404 \\
\hline
\end{tabular}

Solutions with low $\mathrm{Cl}^{-}$concentration (1-3, $\mathrm{Cu}: \mathrm{Cl}$ ratio 1:5) show higher conductivity (Figure 1a) than the solutions with high $\mathrm{Cl}^{-}$concentration (4-6, $\mathrm{Cu}: \mathrm{Cl}$ ratio 1:7). The addition of an increasing amount of $\mathrm{CaCl}_{2}$ causes a significant increase in viscosity and density (Figure $1 \mathrm{~b}, \mathrm{c})$. Solution 6 was the best performing with $\mathrm{Cu}: \mathrm{Cl} 1: 7$ ratio, accordingly with a lower concentration of $\mathrm{CaCl}_{2}$ than solutions 4 and 5 .

Figure 2 shows the $\mathrm{CVs}$ of the $1-6$ solutions carried out at $40{ }^{\circ} \mathrm{C}$ and $0.1 \mathrm{~V} \mathrm{~s}^{-1}$. Our systems are quasi reversible. They do not display a Nernstian reversibility, given that the separation between the cathodic and the anodic peak potentials $(\Delta \mathrm{E})$ is higher than $2.22 \mathrm{RT} / \mathrm{F}\left(59 \mathrm{mV}\right.$ at $\left.40^{\circ} \mathrm{C}\right)$ [33]. However, we focused our attention on the $\mathrm{i}_{\mathrm{pa}} / \mathrm{i}_{\mathrm{pc}}$ ratio that for a totally reversible system must be 1 , independent of the scan rate [34]. This denotes whether an active species can be subsequently reduced and oxidized.

Solutions 1-3 (Figure 2a) shows lower separation between the anodic and cathodic peaks $(\Delta \mathrm{E})$ with respect to the $4-6$ solutions (Figure $2 \mathrm{~b}$ ). In particular, the reversibility is higher for solution 3, without $\mathrm{CaCl}_{2}$, and for the mixed $\mathrm{Cu}^{+} / \mathrm{Cu}^{2+}$ solution 2. Solution 5 also displays an $\mathrm{i}_{\mathrm{pa}} / \mathrm{i}_{\mathrm{pc}}$ ratio near 1 even if the $\Delta \mathrm{E}$ is higher, probably due to the low conductivity and high viscosity.

Data from CVs are collected in Table 2 that reports the open circuit potential vs. SCE (OCP), the peak potentials vs. saturated calomel electrode (SCE) of the anodic and cathodic processes $\left(\mathrm{E}_{+}\right.$and $\left.\mathrm{E}_{-}\right)$, the separation between the peak potentials $(\Delta \mathrm{E})$, the potential of the redox couple $\mathrm{Cu}^{+} / \mathrm{Cu}^{2+}$ calculated by the half-sum of the peak potentials, and the anodic and cathodic peak current densities $\left(\mathrm{i}_{\mathrm{pa}}\right.$ and $\left.\mathrm{i}_{\mathrm{pc}}\right)$ and their ratios. 

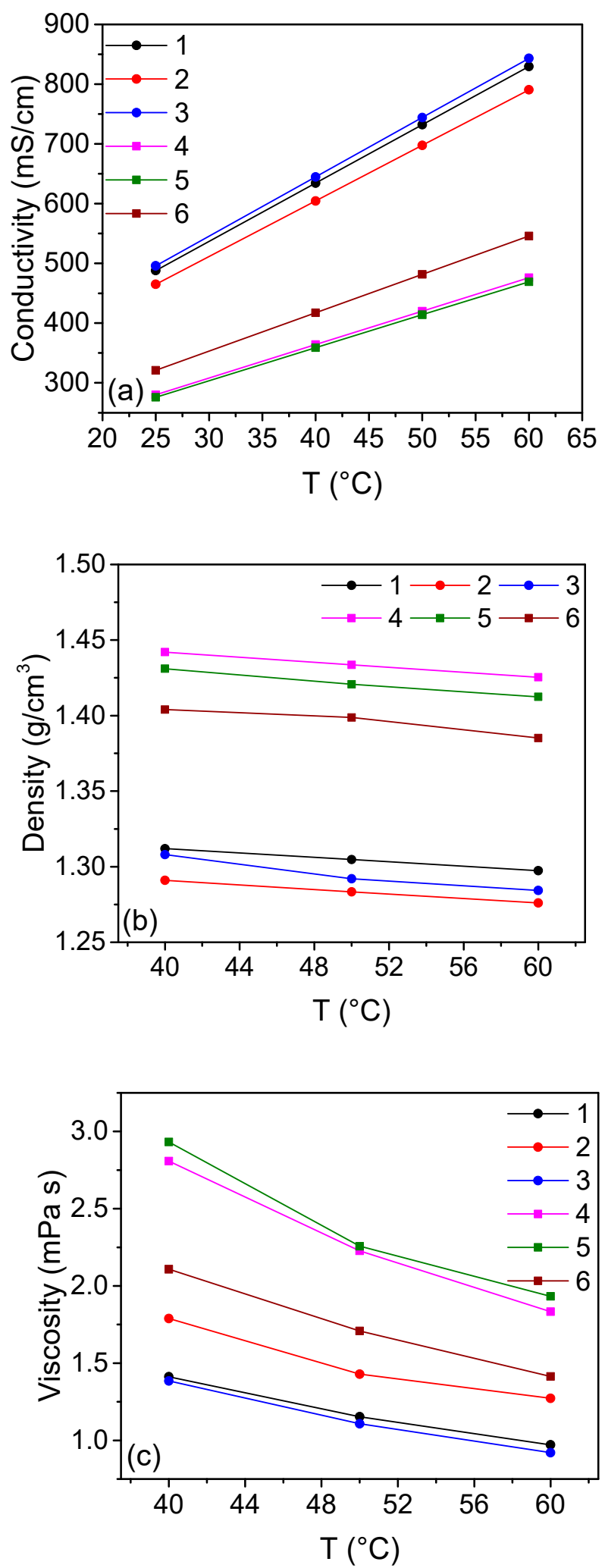

Figure 1. Conductivity (a), density (b), and viscosity (c) of copper electrolytes with $\mathrm{Cu}: \mathrm{Cl}$ ratios of 1:5 (solutions 1-3) and 1:7 (solutions 4-6) at different temperatures. The solution total copper and $\mathrm{HCl}$ concentrations were $2 \mathrm{M}$ and $6 \mathrm{M}$, respectively. Solution compositions are shown in Table 1. 

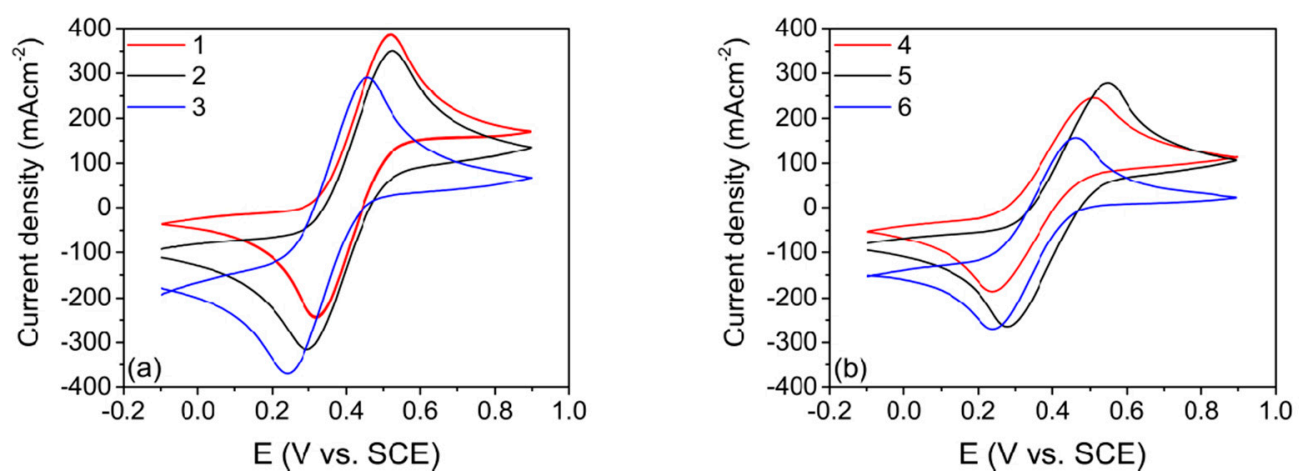

Figure 2. $\mathrm{CVs}$ of the $\mathrm{GC}$ electrode in solutions with different concentrations of copper and calcium chloride with $\mathrm{Cu}: \mathrm{Cl}$ ratio 1:5 (a) and 1:7 (b) at $0.1 \mathrm{~V} \mathrm{~s}^{-1}$ and $40{ }^{\circ} \mathrm{C}$.

Table 2. Electrochemical properties on GC at $0.01 \mathrm{~V} \mathrm{~s}^{-1}$ and $40{ }^{\circ} \mathrm{C}$ of copper electrolytes with different concentrations of copper and calcium chloride for $\mathrm{Cu}: \mathrm{Cl}$ ratios of 1:5 (solutions 1-3) and 1:7 (solutions 4-6). The relative errors of potential measurements are ca. $0.5 \%$ and those related to the current measurements are ca. $1 \%$.

\begin{tabular}{|c|c|c|c|c|c|c|c|c|}
\hline$n$ & $\begin{array}{c}\text { OCP } \\
\text { V } \\
\text { vs. SCE }\end{array}$ & $\begin{array}{c}\text { E }_{+} \\
\text {V } \\
\text { vs. SCE }\end{array}$ & $\begin{array}{c}E_{-} \\
\text {V } \\
\text { vs. SCE }\end{array}$ & $\begin{array}{l}\Delta \mathrm{E} \\
\mathrm{V}\end{array}$ & $\begin{array}{c}\left(E_{+}+E_{-}\right) / 2 \\
V\end{array}$ & $\begin{array}{c}\mathbf{i}_{\mathrm{pa}} \\
\mathrm{mA} \mathrm{cm}^{-2}\end{array}$ & $\begin{array}{c}\mathbf{i}_{\mathbf{p c}} \\
\mathrm{mA} \mathrm{cm}^{-2}\end{array}$ & $\mathbf{i}_{\mathrm{pa}} / \mathbf{i}_{\mathrm{pc}}$ \\
\hline 1 & 0.309 & 0.483 & 0.347 & 0.136 & 0.415 & 149 & -171 & 0.87 \\
\hline 2 & 0.409 & 0.469 & 0.340 & 0.129 & 0.405 & 162 & -163 & 0.99 \\
\hline 3 & 0.622 & 0.419 & 0.299 & 0.120 & 0.359 & 151 & -151 & 1 \\
\hline 4 & 0.302 & 0.447 & 0.296 & 0.151 & 0.372 & 112 & -107 & 1.05 \\
\hline 5 & 0.417 & 0.481 & 0.340 & 0.141 & 0.411 & 117 & -118 & 0.99 \\
\hline 6 & 0.525 & 0.430 & 0.293 & 0.137 & 0.362 & 107 & -113 & 0.95 \\
\hline
\end{tabular}

The combination of $\mathrm{HCl}$ with $\mathrm{CaCl}_{2}$ with $\mathrm{Cu}: \mathrm{Cl}$ ratio 1:5 seems the most promising in terms of conductivity, viscosity, and density as positive copper-chloride electrolytes.

However, $\mathrm{Cl}^{-}$concentration plays a crucial role in the copper speciation considering that the formation constant for $\mathrm{CuCl}_{\mathrm{x}}{ }^{2-\mathrm{x}}$ depends on it. By adding calcium chloride, the chloride concentration, i.e., the availability of complexing agents for copper, should be increased. The $\left(\mathrm{E}_{+}+\mathrm{E}_{-}\right) / 2$ does not change significantly when the chloride concentration increases. In high concentrated solution, calcium chloride is not completely dissociated [35] and theoretical work [36] has shown that $\mathrm{Ca}^{2+}$ can coordinate chloride to form chlorocomplexes even if the $\left[\mathrm{CaCl}_{\mathrm{x}}\right]^{2-\mathrm{x}}(\mathrm{x}=4-6)$ clusters become metastable when hydration is considered. The high ionic strength of the solution used implies a low water content for the complete solvation of calcium.

Hence, to increase the chloride availability in copper solutions and improve the solutions' chemical-physical properties, two main approaches are outlined. The former is the use of a different chloride source, $\mathrm{CaCl}_{2}$ concentration representing the critical factor in terms of conductivity and viscosity as shown for solutions 4-6. The latter is the use of an additive able to interact with $\mathrm{Ca}^{2+}$ and, in turn, to weaken the interaction between $\mathrm{Ca}^{2+}$ and $\mathrm{Cl}^{-}$.

\subsection{Solutions Containing $\mathrm{NH}_{4} \mathrm{Cl}$ as Chloride Source}

The chloride salts and additive selection for CuRFB technology is not very wide because of solubility and overall sustainability. $\mathrm{CaCl}_{2}$ was the preferred source of chloride ions in previous works due to its high solubility, low cost, and availability, being also a bi-equivalent source of chloride. However, a high amount of calcium chloride leads to increased viscosity and density, which adversely impacts the electrolyte hydraulic circuit of the CuRFB, as well as to a decreased conductivity.

Among the different chloride salts, $\mathrm{NH}_{4} \mathrm{Cl}$ shows high solubility in water and low cost. The solutions 7 and 8 were prepared by replacing calcium chloride with ammonium 
chloride, as shown in Table 3, and Figure 3 displays conductivity, density, and viscosity at different temperatures. The conductivity (Figure 3a) of solutions 7 and 8 are significantly higher than that of the corresponding solution with $\mathrm{CaCl}_{2}$ (solutions 1 and 2). The density (Figure $3 b$ ) and the viscosity (Figure $3 c$ ) values are comparable and even lower than those of solutions 1 and 2 (Table 1).

Table 3. Physicochemical properties at $40^{\circ} \mathrm{C}$ and $60^{\circ} \mathrm{C}$ of copper electrolytes with different concentrations of copper and ammonium chloride with $\mathrm{Cu}: \mathrm{Cl}$ ratio of 1:5. The relative errors of conductivity, viscosity, and density measurements are $0.5 \%, 0.35 \%$, and $0.1 \%$, respectively.

\begin{tabular}{|c|c|c|c|c|c|c|c|c|c|c|}
\hline$n$ & $\begin{array}{c}\mathrm{T} \\
{ }^{\circ} \mathrm{C}\end{array}$ & $\begin{array}{c}\mathrm{CuCl}_{2} \\
\mathrm{M}\end{array}$ & $\begin{array}{c}\mathrm{CuCl} \\
\mathbf{M}\end{array}$ & $\begin{array}{c}\mathrm{CaCl}_{2} \\
\mathrm{M}\end{array}$ & $\begin{array}{c}\mathrm{HCl} \\
\mathbf{M}\end{array}$ & $\begin{array}{c}\mathrm{NH}_{4} \mathrm{Cl} \\
\mathrm{M}\end{array}$ & $\mathrm{Cu}: \mathrm{Cl}$ & $\begin{array}{c}\sigma \\
\mathrm{mS} \mathrm{cm}^{-1}\end{array}$ & $\stackrel{\eta}{\mathrm{mPa} s}^{\eta}$ & $\begin{array}{c}\rho \\
\mathrm{kg} \mathrm{m}^{-3}\end{array}$ \\
\hline $7 a$ & 40 & / & 2 & / & 6 & 2 & $1: 5$ & 812 & 1.08 & 1296 \\
\hline $7 b$ & 60 & / & 2 & / & 6 & 2 & $1: 5$ & 1003 & 0.76 & 1283 \\
\hline $8 a$ & 40 & 1 & 1 & / & 6 & 1 & $1: 5$ & 819 & 1.33 & 1250 \\
\hline $8 b$ & 60 & 1 & 1 & / & 6 & 1 & $1: 5$ & 1012 & 0.83 & 1236 \\
\hline
\end{tabular}
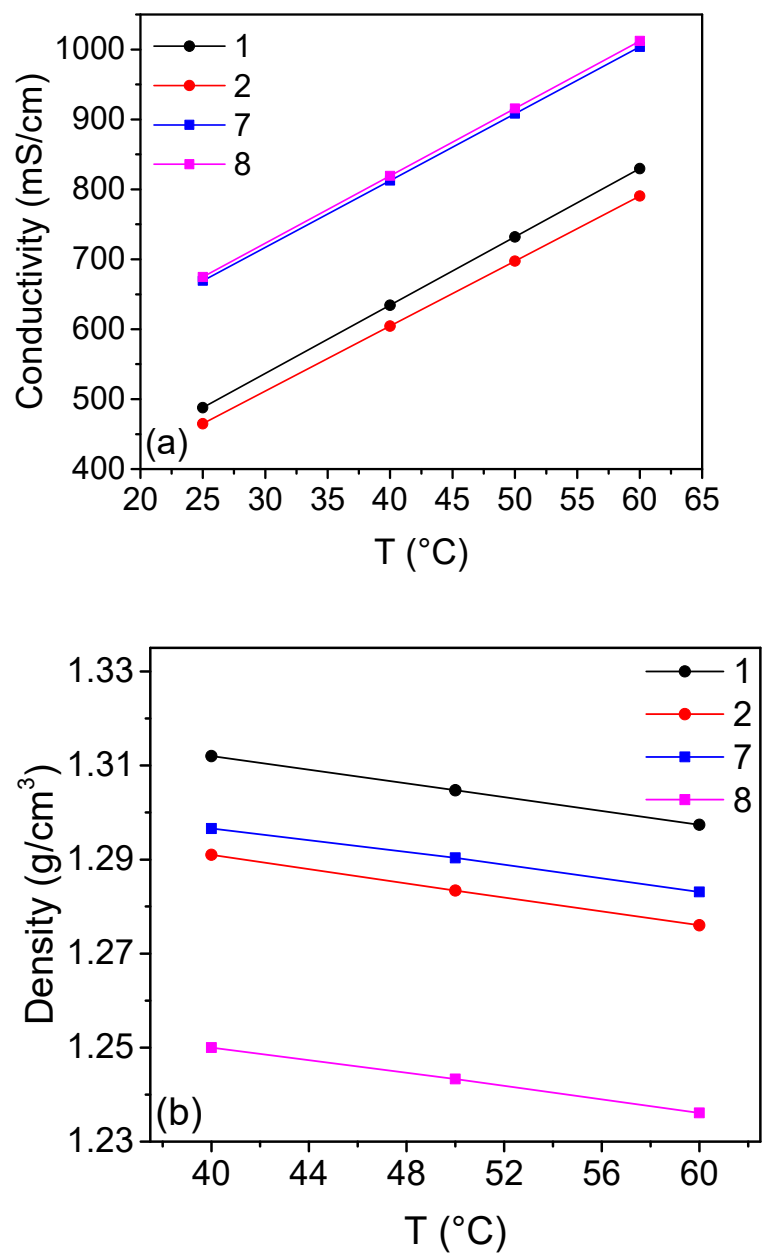

Figure 3. Cont. 


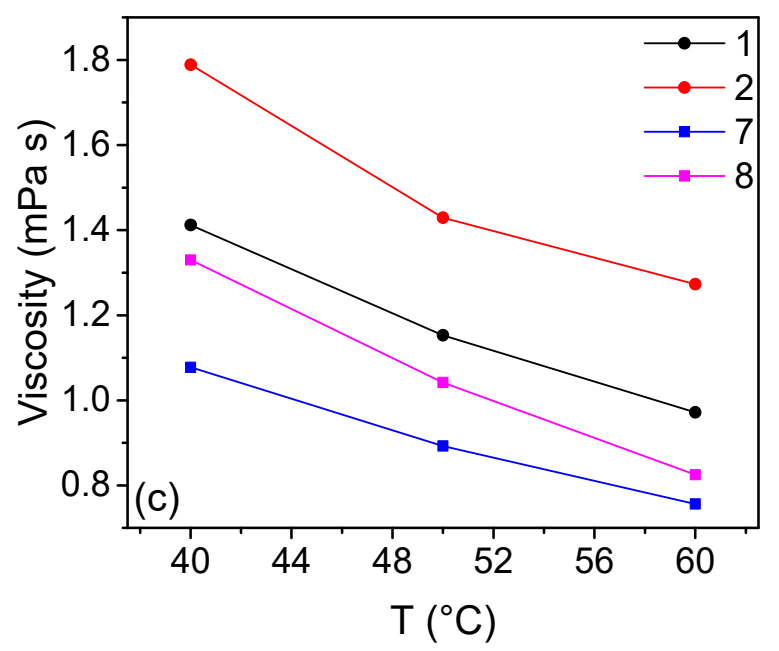

Figure 3. Conductivity (a), density (b), and viscosity (c) of copper electrolytes with $\mathrm{Cu}: \mathrm{Cl}$ ratio of 1:5 (solutions 7 and 8, see Table 3) at different temperatures. The total copper and $\mathrm{HCl}$ concentrations were $2 \mathrm{M}$ and $6 \mathrm{M}$, respectively.

The CVs reported in Figure $4 \mathrm{a}, \mathrm{b}$ for the solutions $7 \mathrm{a}$ and $8 \mathrm{a}$ at $40^{\circ} \mathrm{C}$ show a resistive shape due to crystal precipitation on the electrode surface during the reduction. CVs became more reversible by increasing the temperature up to $60^{\circ} \mathrm{C}$ (solution $7 \mathrm{~b}$ ) with an $\mathrm{i}_{\mathrm{pa}} / \mathrm{i}_{\mathrm{pc}}$ ratio near 1 . Also $\Delta \mathrm{E}$ values decreased both in the $\mathrm{Cu}(\mathrm{I})$ and in the $\mathrm{Cu}(\mathrm{I}) / \mathrm{Cu}(\mathrm{II})$ solutions at $60{ }^{\circ} \mathrm{C}$. Additionally, by increasing the temperature, the potentials shifted toward positive values, as shown in Table 4 which shows the electrochemical parameters of solutions 7 and 8 at $40^{\circ} \mathrm{C}$ and $60^{\circ} \mathrm{C}$.

From the electrochemical results, it is evident that, despite the good physicochemical properties, the solutions with $\mathrm{NH}_{4} \mathrm{Cl}$ are not preferable to those with $\mathrm{CaCl}_{2}$ in the positive half-cell of the CuRFB. On the other hand, looking at the deposition-stripping processes occurring in solution $7 \mathrm{~b}$ compared to those in solution 1 , the addition of ammonium chloride to the electrolyte greatly improved the coulombic efficiency (CE) evaluated by the ratio between the stripping and deposition charges. CVs in the potential range of copper deposition-stripping in the electrolyte with calcium chloride (solution 1, Figure 4c) revealed a CE around $50 \%$ on the GC electrode. After 10 consecutive cycles, the potential at which the copper deposition starts drops from $0.325 \mathrm{~V}$ to $0.300 \mathrm{~V}$ vs. SCE due to the incomplete stripping of copper deposit.

On adding $\mathrm{NH}_{4} \mathrm{Cl}$ to the electrolyte (solution $7 \mathrm{~b}$, Figure $4 \mathrm{~d}$ ), the $\mathrm{CE}$ increased to $85 \%$ and the overpotential of the copper deposition results were unvaried upon cycling. The addition of $\mathrm{NH}_{4} \mathrm{Cl}$ to the negative half-cell electrolyte led to increased reversibility of the negative process by restoring the electrode surface after the copper stripping. It is worth noting that ammonium chloride is used in metalworks for polishing metal surfaces by metal oxides [37] and it could be very useful for improving the performance of the negative half-cell in CuRFB.

Figure 4e,f show the SEM images of copper deposited on Sigracell FR10 graphite at $80 \mathrm{~mA} \mathrm{~cm}^{-2}$ for $1200 \mathrm{~s}$ at $60^{\circ} \mathrm{C}$ in solution 1 and solution $7 \mathrm{~b}$. The images show that smaller grain copper deposits are achieved from the calcium chloride (solution 1) while a larger grain deposit is observed with the ammonium chloride (solution $7 \mathrm{~b}$ ) based electrolyte. The deposits from solution 1 also appear to have more isolated (some triangular type) crystalline features which could be detached from the surface during dissolution without contributing to the efficiency of the reaction. The more coherent deposit from solution $7 \mathrm{~b}$ may explain why a significantly higher $\mathrm{CE}$ is attained in that electrolyte. 

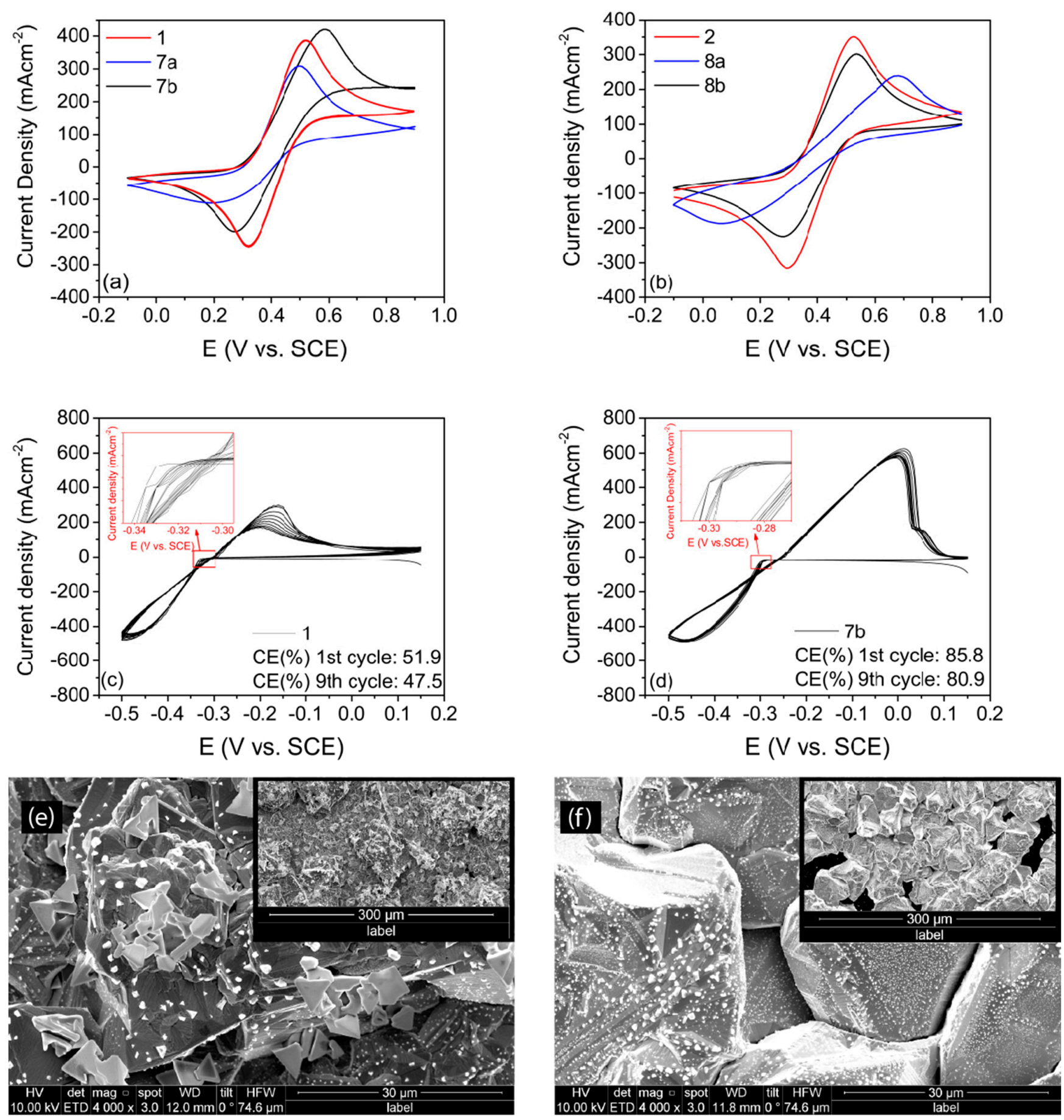

Figure 4. CVs of GC electrode at $0.1 \mathrm{~V} \mathrm{~s}^{-1}$ of (a) the solution 1, 7 and (b) 2, 8 in which 1,2, 7a, and 8a were carried out at $40{ }^{\circ} \mathrm{C}$, while $7 \mathrm{~b}$ and $8 \mathrm{~b}$ were at $60^{\circ} \mathrm{C}$; Cu deposition stripping at $0.1 \mathrm{~V} \mathrm{~s}^{-1}$ and $60^{\circ} \mathrm{C}$ of (c) solution 1 and (d) solution $7 \mathrm{~b}$; SEM images $(4000 \times)$ of copper deposited at $60^{\circ} \mathrm{C}$ in solution $1(\mathbf{e})$ and in solution $7 \mathrm{~b}(\mathbf{f})$. In the inset are the images at $400 \times$ magnification. 
Table 4. Electrochemical properties on GC at $0.01 \mathrm{~V} \mathrm{~s}^{-1}$ and $40{ }^{\circ} \mathrm{C}$ and $60{ }^{\circ} \mathrm{C}$ of copper electrolytes with different concentrations of copper and $\mathrm{NH}_{4} \mathrm{Cl}$ with a $\mathrm{Cu}: \mathrm{Cl}$ ratio of 1:5. The relative errors of potential measurements are ca. $0.5 \%$ and those related to the current measurements are ca. $1 \%$.

\begin{tabular}{|c|c|c|c|c|c|c|c|c|c|}
\hline$n$ & $\begin{array}{c}\mathrm{T} \\
{ }^{\circ} \mathrm{C}\end{array}$ & $\begin{array}{c}\text { OCP } \\
\text { V vs. SCE }\end{array}$ & $\stackrel{E_{+}}{\text {V vs. SCE }}$ & $\begin{array}{c}E_{-} \\
\text {V vs. SCE }\end{array}$ & $\begin{array}{l}\Delta \mathrm{E} \\
\mathrm{V}\end{array}$ & $\begin{array}{c}\left(E_{+}+E_{-}\right) / 2 \\
V\end{array}$ & $\begin{array}{c}\mathrm{i}_{\mathbf{p a}} \\
\mathrm{mA} / \mathrm{cm}^{-2}\end{array}$ & $\begin{array}{c}\mathbf{i}_{\mathbf{p c}} \\
\mathrm{mAcm}^{-2}\end{array}$ & $\mathrm{i}_{\mathrm{pa}} / \mathbf{i}_{\mathrm{pc}}$ \\
\hline $7 a$ & 40 & 0.324 & 0.548 & 0.283 & 0.265 & 0.416 & 150 & -126 & 1.19 \\
\hline $7 b$ & 60 & 0.324 & 0.550 & 0.309 & 0.241 & 0.430 & 211 & -216 & 0.98 \\
\hline $8 a$ & 40 & 0.375 & 0.528 & 0.270 & 0.258 & 0.399 & 125 & -143 & 0.87 \\
\hline $8 b$ & 60 & 0.380 & 0.484 & 0.326 & 0.158 & 0.405 & 146 & -170 & 0.86 \\
\hline
\end{tabular}

Diffusion coefficients were evaluated for selected solutions by chronoamperometric techniques at a potential of $\left(\mathrm{i}_{\mathrm{pa}}+0.1 \mathrm{~V}\right)$ vs. SCE for $\mathrm{Cu}(\mathrm{I})$ oxidation or $\left(\mathrm{i}_{\mathrm{pc}}-0.1 \mathrm{~V}\right)$ vs. SCE for $\mathrm{Cu}$ (II) reduction. The tests were carried out with a GC working electrode ( $3 \mathrm{~mm}$ diameter) to avoid the contribution of edge effects originating from radial contributions [38].

Figure 5 shows the chronoamperometric curves of the solutions 1,4 , and 7 a at $40{ }^{\circ} \mathrm{C}$ and the fitting of the curves $i$ vs. $t^{-1 / 2}$ according to the Cottrell equation in a time range from $0.5 \mathrm{~s}$ to $2 \mathrm{~s}$. As shown in Figure 5b, solution 4 has the lowest diffusion coefficient, even lower than solution 1 . The presence of two cations with interconnected equilibria of complexation with the same ligand can decrease the coordination. Less coordinated complexes can show higher diffusion coefficients due to a smaller radius. However, increasing the concentration of calcium chloride, i.e., on increasing the $\mathrm{Cu}: \mathrm{Cl}$ ratio from 1:5 to 1:7, the diffusion coefficients decrease. The increase of the ionic strength of the solutions decreases the mobility of the ions. As previously discussed, increasing the $\mathrm{Cu}: \mathrm{Cl}$ ratio from 1:5 to 1:7 is not beneficial for electrochemical performance. On substituting the $\mathrm{CaCl}_{2}$ with $\mathrm{NH}_{4} \mathrm{Cl}$, the diffusion coefficient increases as a consequence of the lower viscosity of solution $7 \mathrm{a}$ with respect to solution 1 , given that $\mathrm{NH}_{4}{ }^{+}$is a water destructuring ion. This confirms the suitability of ammonium chloride as a chloride source for the negative half-cell.
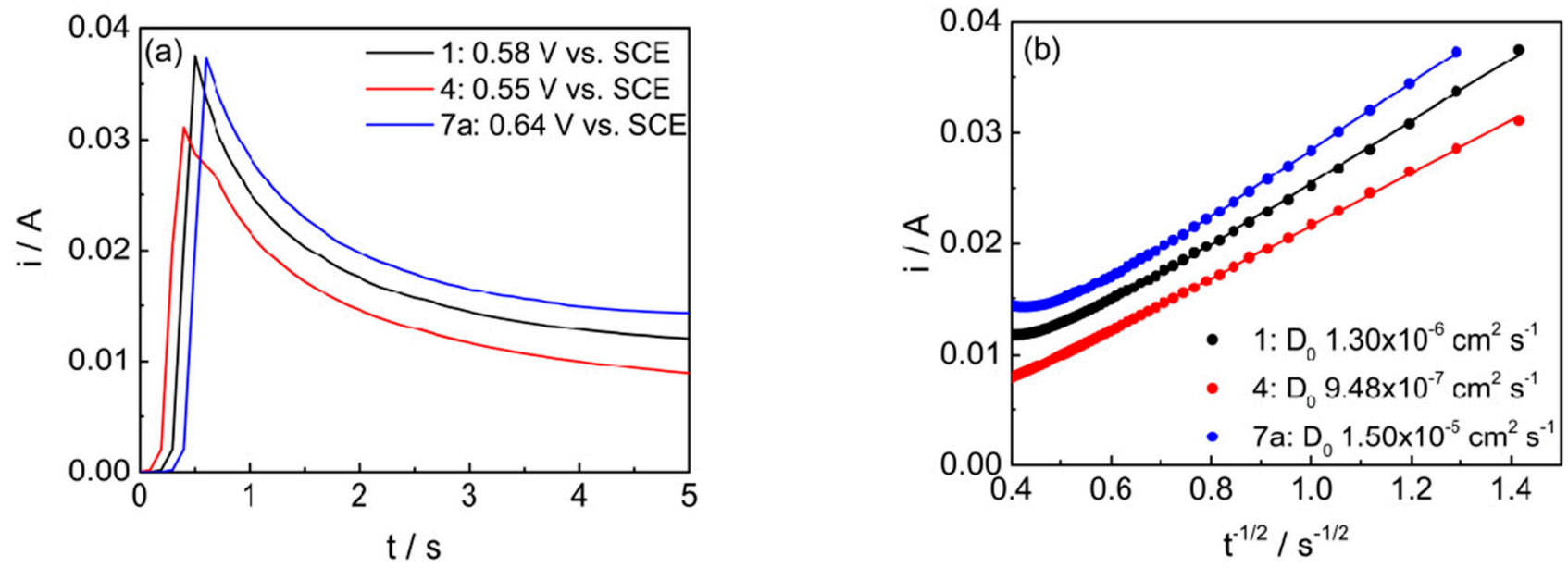

Figure 5. (a) Chronoamperometric curves at ( $i_{p a}+0.1$ V vs. SCE) of solutions 1,4 and 7 . (b) fitting of the curves $i$ vs. $t^{-1 / 2}$ according to the Cottrell equation in a time range from $0.5 \mathrm{~s}$ to $2 \mathrm{~s}(\mathbf{b})$.

\subsection{Solutions Containing $\mathrm{H}_{3} \mathrm{PO}_{4}$ as Additive}

Additives including big anions can influence the equilibria of $\mathrm{Cu}^{+}$and $\mathrm{Ca}^{2+}$ chlorocomplexes. As an example, $\mathrm{Ca}^{2+}$ and $\mathrm{PO}_{4}{ }^{3-}$ interact and $\mathrm{CaCl}_{2}$ and $\mathrm{H}_{3} \mathrm{PO}_{4}$ are used as precursors for the formation of calcium phosphates [39]. For this reason, orthophosphoric acid can be used to decrease the calcium chloride coordination. $\mathrm{Ca}^{2+}$ chloro-complexes become destabilized, and the "free" $\mathrm{Cl}^{-}$can shift the equilibrium of the copper complex formation toward a more coordinated species. Additionally, the introduction of protons 
instead of other cations could be favorable for the conductivity and to avoid further foreign species in the electrolyte.

Two solutions containing $\mathrm{H}_{3} \mathrm{PO}_{4}$ were prepared: solution 10 , where $\mathrm{H}_{3} \mathrm{PO}_{4}$ was added to formulation $1\left(0 \%\right.$ SoC), and solution 11 , in which both $\mathrm{CuCl}$ and $\mathrm{CuCl}_{2}$ were present, and where $\mathrm{CaCl}_{2}$ had a concentration of $1 \mathrm{M}$ for a better comparison with solutions 1 and 10. Considering that, in the RFB system, the SoC is limited at $90 \%$, the mixed $\mathrm{Cu}^{+} / \mathrm{Cu}^{2+}$ solutions prepared should mimic the $90 \%$ SoC. To investigate the effect of phosphate on calcium chloride dissociation, solution 9 with the same composition as solution 11 without $\mathrm{H}_{3} \mathrm{PO}_{4}$ was also prepared. Table 5 reports the physicochemical parameters of these solutions with and without $\mathrm{H}_{3} \mathrm{PO}_{4}$ additive.

Table 5. Physico-chemical properties on GC at $0.01 \mathrm{~V} \mathrm{~s}^{-1}$ and $40{ }^{\circ} \mathrm{C}$ of copper electrolytes with different concentrations of copper and $\mathrm{H}_{3} \mathrm{PO}_{4}$ with $\mathrm{Cu}: \mathrm{Cl}$ ratio of 1:5. The relative errors of conductivity, viscosity, and density measurements are $0.5 \%, 0.35 \%$, and $0.1 \%$, respectively.

\begin{tabular}{cccccccccc}
\hline $\boldsymbol{n}$ & $\begin{array}{c}\mathrm{CuCl}_{2} \\
\mathbf{M}\end{array}$ & $\begin{array}{c}\mathrm{CuCl} \\
\mathbf{M}\end{array}$ & $\begin{array}{c}\mathrm{CaCl}_{\mathbf{2}} \\
\mathbf{M}\end{array}$ & $\begin{array}{c}\mathbf{H C l} \\
\mathbf{M}\end{array}$ & $\begin{array}{c}\mathbf{H}_{3} \mathbf{P O}_{4} \\
\mathbf{M}\end{array}$ & $\mathbf{C u : C l}$ & $\begin{array}{c}\sigma \\
\mathbf{m S ~ c m}\end{array}$ & $\begin{array}{c}\eta \\
\mathbf{m P a}\end{array}$ & $\begin{array}{c}\boldsymbol{\rho} \\
\mathbf{k g ~ m}^{-3}\end{array}$ \\
\hline 1 & $/$ & 2 & 1 & 6 & $/$ & $1: 5$ & 634 & 1.41 & 1312 \\
9 & 1.8 & 0.2 & 1 & 6 & $/$ & $1: 5.9$ & 569 & 1.73 & 1347 \\
10 & $/$ & 2 & 1 & 6 & 1 & $1: 5$ & 714 & 1.62 & 1300 \\
11 & 1.8 & 0.2 & 1 & 6 & 1 & $1: 5.9$ & 508 & 1.66 & 1334 \\
\hline
\end{tabular}

Figure 6 summarizes the results of conductivity, density, and viscosity at different temperatures of the solution reported in Table 5.

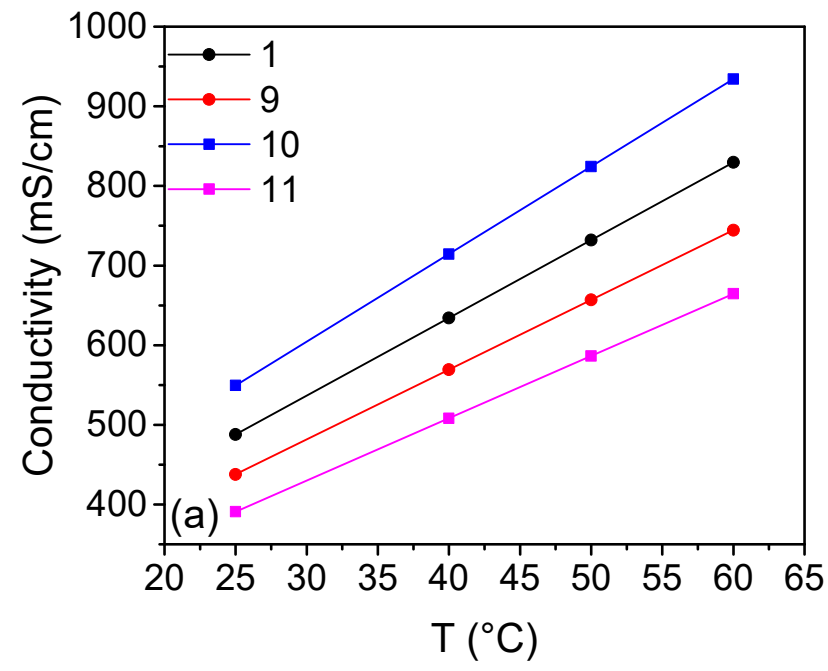

Figure 6. Cont. 

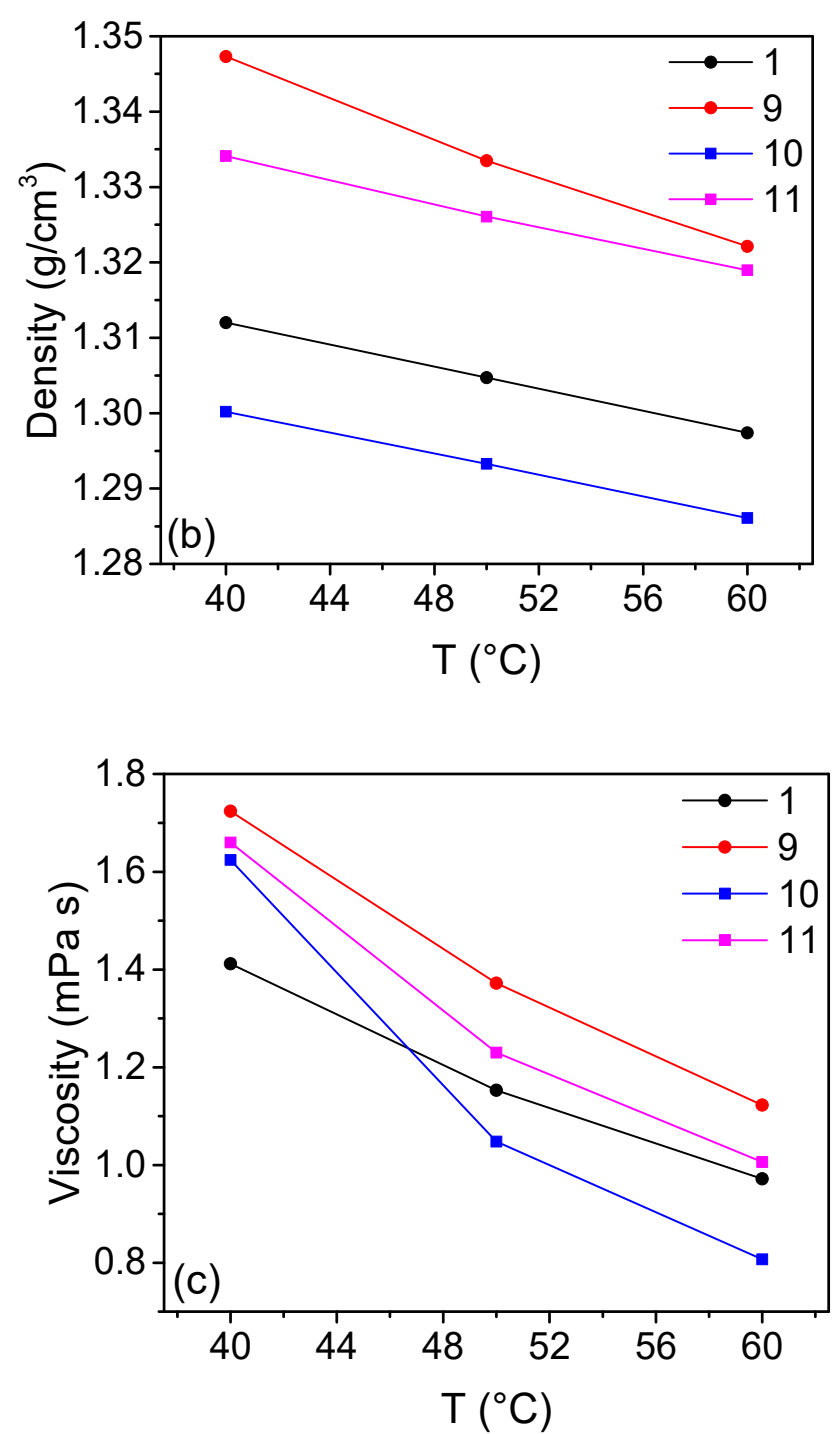

Figure 6. Conductivity (a), density (b), and viscosity (c) of copper electrolytes with $\mathrm{Cu}: \mathrm{Cl}$ ratio of 1:5 (solutions 1 and 9 without $\mathrm{H}_{3} \mathrm{PO}_{4}$, and solution 10 and 11, with $\mathrm{H}_{3} \mathrm{PO}_{4}$ ) at different temperatures. The total copper and $\mathrm{HCl}$ concentrations were $2 \mathrm{M}$ and $6 \mathrm{M}$, respectively.

Figure 6 shows that the addition of phosphoric acid to formulation 1 (solution 10) leads to a conductivity increase, due to the increase in $\mathrm{H}_{3} \mathrm{O}^{+}$concentration, despite a higher viscosity. The parameters of the solutions show the opposite trend for solutions 9 and 11, with a decreased conductivity for solution 11 and a slight decrease of density and viscosity with respect to solution 9. The latter solutions have higher ionic strength $(\mathrm{Cu}: \mathrm{Cl}$ ratio of 1:5.9) than the solutions 1 and 10, and the addition of phosphoric acid further increases it. In this case, presumably, the conduction mechanism of $\mathrm{H}_{3} \mathrm{O}^{+}$is hindered by the increase of $\mathrm{Cl}^{-}$concentration, $\mathrm{Cl}^{-}$being a water-destructuring ion.

Table 6 reports the electrochemical properties of the solutions of Table 5 while Figure 7 displays the $\mathrm{CVs}$ at $40^{\circ} \mathrm{C}$. For the solution of $\mathrm{Cu}(\mathrm{I})$ (Figure 7a), the addition of orthophosphoric acid increases and improves the reversibility of the $C V\left(i_{p a} / i_{p c}\right.$ ratio), with the potential of the redox couple shifted towards less positive values. In highly concentrated $\mathrm{Cu}$ (II) electrolytes, the reversibility results increased (Figure $7 \mathrm{~b}$ ) despite the lower conductivity of solution 11 with respect to 9 . The $\Delta \mathrm{E}$ is reduced from $268 \mathrm{mV}$ to $167 \mathrm{mV}$ and, the $\mathrm{i}_{\mathrm{pa}} / \mathrm{i}_{\mathrm{pc}}$ ratio approaches 1 . 
Table 6. Electrochemical properties at $40{ }^{\circ} \mathrm{C}$ of copper electrolytes with $\mathrm{CaCl}_{2}$, with and without $\mathrm{H}_{3} \mathrm{PO}_{4}$ with a $\mathrm{Cu}: \mathrm{Cl}$ ratio of 1:5. The relative errors of potential measurements are ca. $0.5 \%$ and those related to the current measurements are ca. $1 \%$.

\begin{tabular}{|c|c|c|c|c|c|c|c|c|}
\hline$n$ & $\begin{array}{l}\text { OCP } \\
\text { V vs. } \\
\text { SCE }\end{array}$ & $\begin{array}{c}\mathrm{E}_{+} \\
\mathrm{V} \text { vs. } \\
\text { SCE }\end{array}$ & $\begin{array}{c}E_{-} \\
\text {V vs. } \\
\text { SCE }\end{array}$ & $\begin{array}{l}\Delta \mathrm{E} \\
\mathrm{V}\end{array}$ & $\begin{array}{c}\left(E_{+}+\right. \\
\left.E_{-}\right) / 2 \\
V\end{array}$ & $\begin{array}{c}\mathbf{i}_{\mathbf{p a}} \\
\mathbf{m A} \\
\mathrm{cm}^{-2}\end{array}$ & $\begin{array}{c}\mathrm{i}_{\mathrm{pc}} \\
\mathrm{mA} \\
\mathrm{cm}^{-2}\end{array}$ & $\mathbf{i}_{\mathrm{pa}} / \mathbf{i}_{\mathrm{pc}}$ \\
\hline 1 & 0.309 & 0.483 & 0.347 & 0.136 & 0.415 & 149 & -171 & 0.87 \\
\hline 9 & 0.490 & 0.477 & 0.209 & 0.268 & 0.343 & 127 & -120 & 1.06 \\
\hline 10 & 0.297 & 0.473 & 0.309 & 0.164 & 0.391 & 142 & -154 & 0.92 \\
\hline 11 & 0.427 & 0.444 & 0.277 & 0.167 & 0.361 & 125 & -120 & 1.04 \\
\hline
\end{tabular}
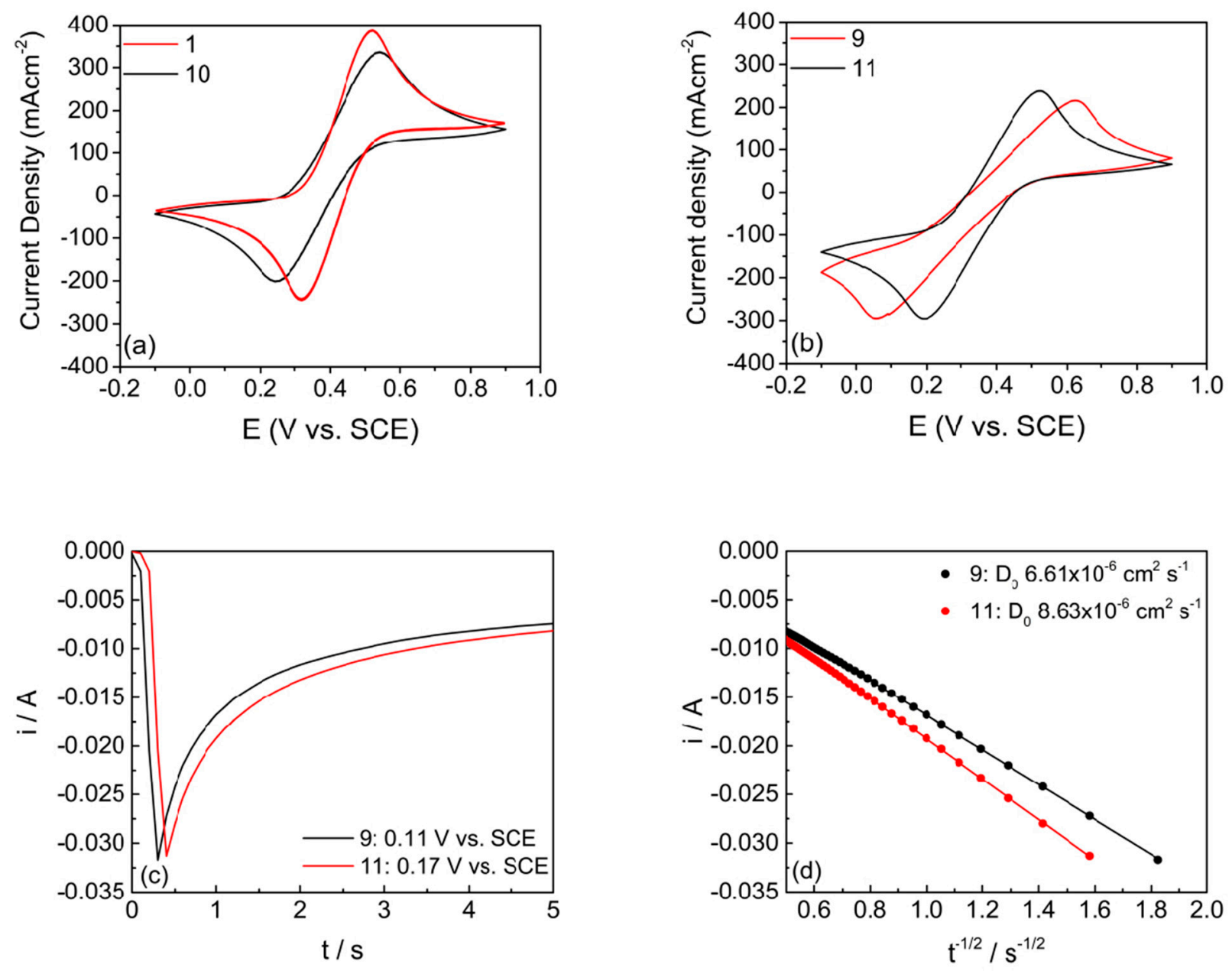

Figure 7. CVs of GC electrode at $0.1 \mathrm{~V} \mathrm{~s}^{-1}$ and $40{ }^{\circ} \mathrm{C}$ in solutions with different concentrations of copper and calcium chloride with and without $\mathrm{H}_{3} \mathrm{PO}_{4}(\mathbf{a})$ at $0 \% \mathrm{SoC}$ and (b) at $90 \%$ SoC. (c) Chronoamperometric curves of $\mathrm{Cu}(\mathrm{II})$ at (i $\mathrm{i}_{\mathrm{pc}}-0.1 \mathrm{~V}$ ) vs. SCE of 9 and 11 solutions $\left(0 \%\right.$ SoC), (d) fitting of the curves i vs. $t^{-1 / 2}$ according to the Cottrell equation in a time range from $0.5 \mathrm{~s}$ to $2 \mathrm{~s}$.

In solutions with a chloride concentration higher than $5 \mathrm{M}, \mathrm{Cu}(\mathrm{I})$ is preferentially present as the most chloro-coordinated species $\mathrm{CuCl}_{3}{ }^{2-}$ [3]. The increased availability of chloride ligands is more effective for $\mathrm{Cu}(\mathrm{II})$-rich electrolytes. Under the same conditions, $\mathrm{Cu}$ (II) chlorocomplexes favour the lower coordination number, and changes in chloride concentration, even at high ligand concentration, can affect the copper chlorocomplex distribution [25]. Hence, copper(I) is less affected by a higher amount of uncomplexed chloride anions than $\mathrm{Cu}(\mathrm{II})$. In oxidized solutions, the chloride released due to the presence 
of phosphoric acid can coordinate the $\mathrm{Cu}$ (II) cations leading to a more reversible and electrochemically stable redox couple.

In solution 9 with $1.8 \mathrm{M} \mathrm{Cu}(\mathrm{II})$, the diffusion coefficient obtained from the Cottrell equation (Figure $7 \mathrm{c}, \mathrm{d}$ ) increases with the addition of $1 \mathrm{M} \mathrm{H}_{3} \mathrm{PO}_{4}$ even as the conductivity of the solution decreases from $569 \mathrm{mS} \mathrm{cm}^{-1}$ to $508 \mathrm{mS} \mathrm{cm}^{-1}$ as a consequence of the higher ionic strength. As observed in the $\mathrm{CV}$ measurements, $\mathrm{H}_{3} \mathrm{PO}_{4}$ is more effective in the $\mathrm{Cu}$ (II) chemical environment with respect to the copper(I). Hence, the $\mathrm{Cu}$ (II) diffusion coefficient varies from $6.6 \times 10^{-6} \mathrm{~cm}^{2} \mathrm{~s}^{-1}$ to $8.6 \times 10^{-6} \mathrm{~cm}^{2} \mathrm{~s}^{-1}$.

Absorption spectroscopy of $\mathrm{Cu}$ (II) halide-complexes has been intensively studied in both aqueous and organic solvents [4,40-42]. The absorption spectrum of copper (II) is characterized by two transitions. In the UV region, the ligand-to-metal charge transfer (LMCT) transition contains information about the degree of complexation, while in the NIR there is a broad metal centered (MC) band ( $d-d$ transition) which is harder to resolve.

The LMCT is too intense in highly concentrated solution, hence, changes in the coordination sphere are established from the MC band. From the crystal field theory, ligands modify the ligand-field splitting parameter $\Delta$ that determines the energy of the MC transition. The presence of chloride ligands in the copper coordination sphere reduces the $\Delta$ and red shift of the MC band with respect to aquo-complex [43].

Figure 8a reports the absorption spectrum in the Vis/NIR region of the high concentrated $\mathrm{Cu}(\mathrm{II}) / \mathrm{Cu}(\mathrm{I})$ solution with the unvaried concentration of $\mathrm{CaCl}_{2}$, i.e., solutions 9 and 11 .
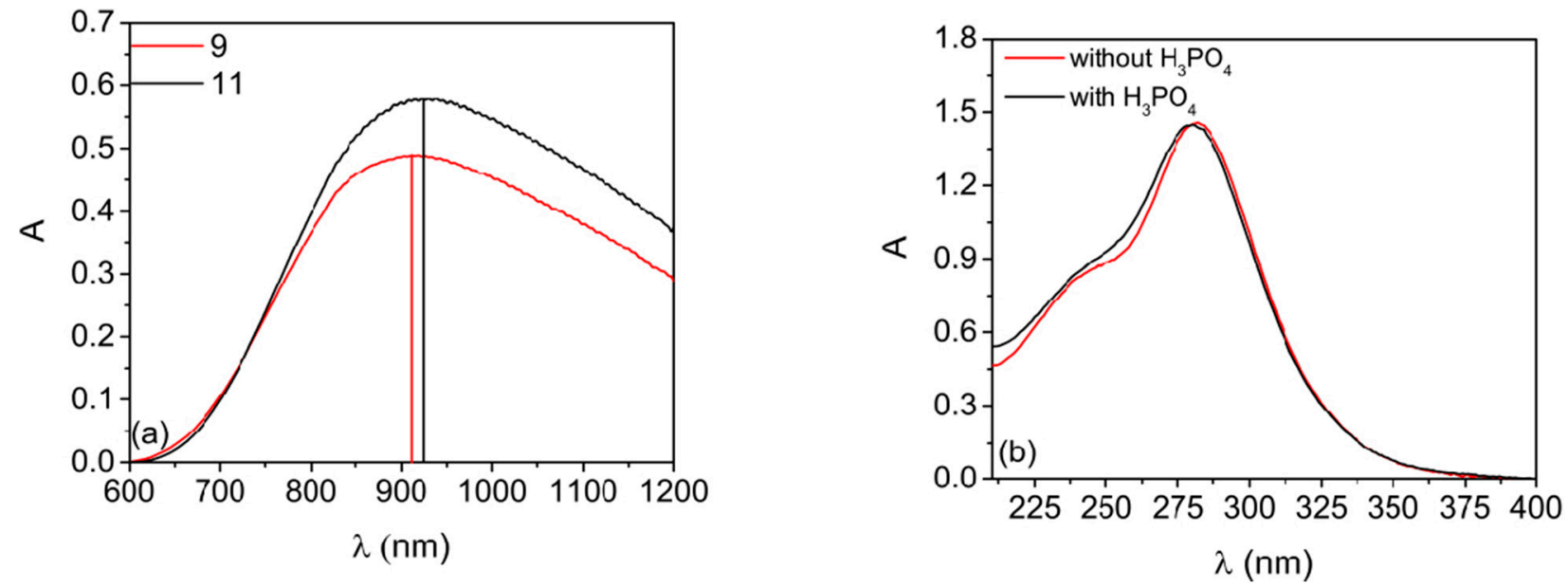

Figure 8. Absorption spectra: (a) MC band of concentrated 9 and 11 solutions with optical path of $50 \mu \mathrm{m}$ and (b) LMCT band of $10 \mathrm{mM} \mathrm{CuCl}_{2}, 10 \mathrm{mM} \mathrm{CaCl}_{2}, 30 \mathrm{mM} \mathrm{HCl}$ with and without $10 \mathrm{mM} \mathrm{H}_{3} \mathrm{PO}_{4}$ (optical path $500 \mu \mathrm{m}$ ).

The addition of $\mathrm{H}_{3} \mathrm{PO}_{4}$ leads to a red shift of $\mathrm{MC}$ from $925 \mathrm{~nm}$ to $910 \mathrm{~nm}$. According to deconvolution of the MC band [4], this shift can be interpreted as a decrease of low chloride-coordinated complexes and an increase of the component for $\mathrm{CuCl}_{3}{ }^{-}$. Differences in absorbance are justified by the different molar extinction coefficients of the complexes involved. On the other hand, phosphate anions do not enter the inner coordination sphere of the copper [44] as demonstrated by the spectra in Figure $8 \mathrm{~b}$ of a diluted solution (200 times) with the same composition of solutions 9 and 11. These spectra show the LMCT bands with an unvaried presence of $\mathrm{CuCl}_{3}{ }^{-}$.

\section{Materials and Methods}

For the solutions $\mathrm{CuCl}_{2}(>99.99 \%$, Sigma Aldrich), $\mathrm{CuCl}$ ( $\geq 99.995 \%$ trace metal basis, Sigma Aldrich, $\mathrm{HCl}$ (37\%, Sigma-Aldrich, Merck KGaA, Darmstadt, Germany), $\mathrm{CaCl}_{2}$ ( $\geq 99 \%$, ACS reagent, Sigma Aldrich, Merck KGaA, Darmstadt, Germany), $\mathrm{NH}_{4} \mathrm{Cl}(99.5 \%$, Sigma Aldrich, Merck KGaA, Darmstadt, Germany) and $\mathrm{H}_{3} \mathrm{PO}_{4}(\geq 85 \mathrm{wt} \%$ solution in water, ACS reagent, Sigma Aldrich, Merck KGaA, Darmstadt, Germany) were used. After 
complete dissolution in deionized water, the solutions were deaerated with Ar for ten minutes and sealed. The solution composition is given in the tables in the results and discussion section, and the solutions are indicated with a number. Conductivity tests were carried out with Sension + EC71 Hach Instruments (Hach Lange GmbH, Düsseldorf, Germany), viscosity tests were performed with SVM 3000 Stabinger Anton Paar (Anton Paar GmbH, Graz, Austria), and density was measured by DMA 4500 Anton Paar (Anton Paar GmbH, Graz, Austria) at different temperatures. Electrochemical tests were carried out under Ar atmosphere in a conventional V-cell, kept in a water bath at $40{ }^{\circ} \mathrm{C}$, with a Voltalab PGZ301 (Radiometer, Copenhagen, Denmark). The cell contained $10 \mathrm{~mL}$ solution. A glassy carbon (GC, $3 \mathrm{~mm}$ diameter) was used as the working electrode, a graphite rod (6 $\mathrm{mm}$ diameter, $15 \mathrm{~cm}$ length, Gamry Instruments, Warminster, PA, USA) as counter electrode and a saturated calomel electrode (SCE, 303/SCG/6J, AMEL, Milan, Italy) as reference electrode. Cyclic voltammetry (CVs) studies were carried out at $40{ }^{\circ} \mathrm{C}$ at different scan rates, from 0.1 to $0.005 \mathrm{~V} \mathrm{~s}^{-1}$. CVs in solutions containing $\mathrm{NH}_{4} \mathrm{Cl}$ were performed at $60{ }^{\circ} \mathrm{C}$. The voltammograms are not live-IR corrected. Scanning Electron Microscopy (SEM) images were collected with an FEI Quanta 650 Scanning Electron Microscope (FEI, Hillsboro, OR, USA). Spectrophotometric tests were performed with a Perkin Elmer Lambda 19 (Perkin Elmer Italia SpA, Milan, Italy) in quartz cells with an optical path length of $50 \mu \mathrm{m}$ in the ultraviolet-visible (UV-Vis) region and $500 \mu \mathrm{m}$ in the near infrared (NIR) region.

\section{Conclusions}

In relation to the growing interest in RFB systems and copper chemistry in solution, different copper electrolytes were characterized for application in CuRFB. The effect of calcium chloride as supporting electrolyte was tested in solution with a $\mathrm{Cu}: \mathrm{Cl}$ ratio of 1:5 and 1:7. Solutions with 1:5 $\mathrm{Cu}: \mathrm{Cl}$ ratio displayed the best performance. The substitution of calcium chloride with ammonium chloride increased the conductivity up to $1000 \mathrm{mS} \mathrm{cm}^{-1}$ without improving the $\mathrm{Cu}(\mathrm{I}) / \mathrm{Cu}$ (II) couple redox processes. On the other hand, the addition of $\mathrm{NH}_{4} \mathrm{Cl}$ to $\mathrm{Cu}(\mathrm{I})$ electrolyte led to improved reversibility of the copper deposition-stripping processes with CE reaching $80 \%$.

The interaction of phosphate with $\mathrm{Ca}^{2+}$ suggested that $\mathrm{H}_{3} \mathrm{PO}_{4}$ could be a viable additive to decrease the complexation of calcium with chloride and to improve $\mathrm{Cu}(\mathrm{II})$ chloro-complex stability. UV-VIS spectroscopy demonstrated that phosphate does not take part in the coordination sphere of $\mathrm{Cu}(\mathrm{II})$. The addition of $\mathrm{H}_{3} \mathrm{PO}_{4}$ in concentrated solution led to a shift in the distribution of copper cholorocomplexes toward more coordinated species visible in the NIR absorption spectrum. Electrochemically, the addition of phosphoric acid is not effective on $\mathrm{Cu}(\mathrm{I})$-rich electrolyte due to the lower amount of chloride required for coordination. The increased availability of chloride anions in solution stabilizes the $\mathrm{Cu}(\mathrm{II})$-rich solution and leads to increased reversibility of the $\mathrm{Cu}(\mathrm{II}) / \mathrm{Cu}(\mathrm{I})$ redox process and higher copper(II) diffusion coefficients.

Author Contributions: Conceptualization, C.A. and G.L.; methodology, G.L., L.F.; experimental investigation and validation, G.L., L.F., S.P., D.P.C.; formal analysis, S.R., J.F.R., P.C.R.; writingoriginal draft preparation, G.L.; writing—review and editing, C.A., S.R., P.C.R., J.F.R.; supervision, C.A.; project administration, C.A., P.C.R., J.F.R.; funding acquisition, C.A., P.C.R., J.F.R. All authors have read and agreed to the published version of the manuscript.

Funding: This work was supported by the European Union within the Horizon 2020 research and innovation programme [CUBER-Copper-Based Flow Battery for Energy storage Renewables Integration H2020-LC-BAT_2019] under grant agreement No. 875605. G.L. acknowledges the Department of Excellence program financed by the Minister of Education, University and Research (MIUR, L. 232 del 01/12/2016) for the doctoral scholarship.

Institutional Review Board Statement: Not applicable.

Informed Consent Statement: Not applicable.

Data Availability Statement: All the date are included in the paper. 
Acknowledgments: All the Project Partners are acknowledged for the fruitful discussion. The Authors thank Lorraine C. Nagle for SEM images.

Conflicts of Interest: The authors declare no conflict of interest.

\section{References}

1. Mussler, R.E.; Campbell, T.T.; Olsen, R.S. Electrowinning of Copper from Chloride Solutions U.S. Dept. of Interior, Bureau of Mines, Report of Investigation 8076, Washington: 1975. Available online: http:/ /books.google.com (accessed on 30 November 2021).

2. Sugasaka, K.; Fujii, A. A Spectrophotometric Study of Copper(I) Chloro-Complexes in Aqueous 5M Na(Cl,ClO4) Solutions. Bull. Chem. Soc. Jpn. 1976, 42, 82-86. [CrossRef]

3. Fritz, J.J. Chloride Complexes of CuCI in Aqueous Solution. J. Phys. Chem. 1980, 84, 2241-2246. [CrossRef]

4. Brugger, J.; McPhail, D.C.; Black, J.; Spiccia, L. Complexation of metal ions in brines: Application of electronic spectroscopy in the study of the $\mathrm{Cu}(\mathrm{II})-\mathrm{LiCl}-\mathrm{H}_{2} \mathrm{O}$ system between 25 and $90^{\circ} \mathrm{C}$. Geoch. Cosmoch. Acta 2001, 65, 2691-2708. [CrossRef]

5. Hyvärinen, O.; Hämäläinen, M.; Lamberg, P.; Liipo, J. Recovering Gold from Copper Concentrate via the HydroCopperTM Process. JOM 2004, 56, 57-59. [CrossRef]

6. Lundström, M.; Aromaa, J.; Forsén, O.; Hyvärinen, O.; Barker, M.H. Cathodic reactions of Cu2+ in cupric chloride solution. Hydrometallurgy 2007, 85, 9-16. [CrossRef]

7. Naterer, G.; Suppiah, S.; Lewis, M.; Gabriel, K.; Dincer, I.; Rosen, M. Recent Canadian advances in nuclear-based hydrogen production and the thermochemical Cu-Cl cycle. Int. J. Hydrogen Energy 2009, 34, 2901-2917. [CrossRef]

8. Trevani, L.; Ehlerova, J.; Sedlbauer, J.; Tremaine, P.R. Complexation in the $\mathrm{Cu}(\mathrm{II})-\mathrm{LiCl}-\mathrm{H}_{2} \mathrm{O}$ system at temperatures to $423 \mathrm{~K}$ by UV-Visible spectroscopy. Int. J. Hydrogen Energy 2010, 35, 4893-4900. [CrossRef]

9. Soltani, R.; Dincer, I.; Rosen, M.A. Electrochemical analysis of a $\mathrm{HCl}(\mathrm{aq}) / \mathrm{CuCl}(\mathrm{aq})$ electrolyzer: Equilibrium thermodynamics. Int. J. Hydrogen Energy 2016, 41, 19, 7835-7847. [CrossRef]

10. Farsi, A.; Zamfirescu, C.; Dincer, I.; Naterer, G.F. Electrochemical Transport in $\mathrm{CuCl} / \mathrm{HCl}(\mathrm{aq})$ Electrolyzer Cells and Stack of the $\mathrm{Cu}-\mathrm{Cl}$ Cycle. J. Electrochem. Soc. 2020, 167, 044515. [CrossRef]

11. Springer, R.; Cross, N.R.; Lvov, S.N.; Logan, B.E.; Gorski, C.A.; Hall, D.M. An All-Aqueous Thermally Regenerative Ammonia Battery Chemistry Using Cu(I, II) Redox Reactions. J. Electrochem. Soc. 2021, 168, 070523. [CrossRef]

12. Kratochvil, B.; Betty, K.R. A Secondary Battery Based on the Copper(II)-(I) and (I)-(0) Couples in Acetonitrile. J. Electrochem. Soc. 1974, 121, 851-854. [CrossRef]

13. Porterfield, W.W.; Yoke, J.T. Inorganic Compounds with Unusual Properties; King, R.B., Ed.; ACS Publications: Washington, DC, USA, 1976; pp. 104-110.

14. Peljo, P.; Lloyd, D.; Doan, N.; Majaneva, M.; Kontturi, K. Towards a thermally regenerative all-copper redox flow battery. Phys. Chem. Chem. Phys. 2014, 16, 2831-2835. [CrossRef] [PubMed]

15. Lloyd, D.; Vainikka, T.; Kontturi, K. The development of an all copper hybrid redox flow battery using deep eutectic solvents. Electrochim. Acta 2013, 100, 18-23. [CrossRef]

16. Sanz, L.; Palma, J.; García-Quismondo, E.; Anderson, M. The effect of chloride ion complexation on reversibility and redox potential of the $\mathrm{Cu}(\mathrm{II}) / \mathrm{Cu}(\mathrm{I})$ couple for use in redox flow batteries. J. Power Sources 2013, 224, 278-284. [CrossRef]

17. Leung, P.; Palma, J.; Garcia-Quismondo, E.; Sanz, L.; Mohamed, M.R.; Anderson, M. Evaluation of electrode materials for all-copper hybrid flow batteries. J. Power Sources 2016, 310, 1-11. [CrossRef]

18. Stricker, E.A.; Krueger, K.W.; Savinell, R.F.; Wainright, J.S. Investigating a Bromide Supported Electrolyte for an All-Copper Flow Battery. J. Electrochem. Soc. 2018, 165, A1797-A1804. [CrossRef]

19. Bartolozzi, M. Development of redox flow batteries. A historical bibliography. J. Power Sources 1989, 27, 219-234. [CrossRef]

20. Parasuraman, A.; Lim, T.M.; Menictas, C.; Skyllas-Kazacos, M. Review of material research and development for vanadium redox flow battery application. Electrochim. Acta 2013, 101, 27-40. [CrossRef]

21. Sánchez-Díez, E.; Ventosa, E.; Guarnieri, M.; Trovò, A.; Flox, C.; Marcilla, R.; Soavi, F.; Mazur, P.; Aranzabe, E.; Ferret, R. Redox flow batteries: Status and perspective towards sustainable stationary energy storage. J. Power Sources 2021, 481, 228804. [CrossRef]

22. Sharma, V.K.; Millero, F.J. Equilibrium Constants for the Formation of Cu(I) Halide Complexes. J. Solut. Chem. 1990, 19, 375-390. [CrossRef]

23. Zhou, Q.; Zeng, D.; Voigt, W. Thermodynamic modeling of salt-water systems up to saturation concentrations based on solute speciation: $\mathrm{CuCl}_{2}-\mathrm{MCln}-\mathrm{H}_{2} \mathrm{O}$ at $298 \mathrm{~K}(\mathrm{M}=\mathrm{Li}, \mathrm{Mg}$, Ca). Fluid Phase Equilibria 2012, 322, 30-40. [CrossRef]

24. Applegarth, L.M.; Corbeil, C.R.; Mercer, D.J.W.; Pye, C.C.; Tremaine, P.R. Raman and ab Initio Investigation of Aqueous Cu(I) Chloride Complexes from 25 to $80^{\circ}$ C. J. Phys. Chem. B 2014, 118, 204-214. [CrossRef] [PubMed]

25. Meng, Y.; Bard, A.J. Measurement of Temperature-Dependent Stability Constants of $\mathrm{Cu}(\mathrm{I})$ and $\mathrm{Cu}(\mathrm{II}) \mathrm{Chloride} \mathrm{Complexes}$ by Voltammetry at a Pt Ultramicroelectrode. Anal. Chem. 2015, 87, 3498-3504. [CrossRef]

26. Stricker, E.A.; Adler, Z.; Wainright, J.S.; Savinell, R.F. Diffusion Coefficients of Cuprous and Cupric Ions in Electrolytes with High Concentration of Bromide Ions. J. Chem. Eng. Data 2019, 64, 1095-1100. [CrossRef]

27. Soltani, R.; Dincer, I.; Rosen, M.A. Kinetic and electrochemical analyses of a CuCI/HCl electrolyzer. Int. J. Energy Res. 2019, 43, 6890-6906. [CrossRef]

28. Hall, M.; Akinfiev, N.N.; LaRow, E.G.; Schatz, R.S.; Lvov, S.N. Thermodynamics and Efficiency of a CuCl(aq)/HCl(aq) Electrolyzer. Electrochim. Acta 2014, 143, 70-82. [CrossRef] 
29. Balashov, N.; Schatz, R.S.; Chalkova, E.; Akinfiev, N.N.; Fedkin, M.V.; Lvov, S.N. CuCl Electrolysis for Hydrogen Production in the $\mathrm{Cu}-\mathrm{Cl}$ Thermochemical Cycle. J. Electrochem. Soc. 2011, 158, B266-B275. [CrossRef]

30. Sanz, L.; Lloyd, D.; Magdalena, E.; Palma, J.; Anderson, M.; Kontturi, K. Study and characterization of positive electrolytes for application in the aqueous all-copper redox flow battery. J. Power Sources 2015, 278, 175-182. [CrossRef]

31. Wu, Z.-C.; Awakura, Y.; Ando, S.; Majima, H. Determination of the Diffusion Coefficients of $\mathrm{CuCl}_{2}, \mathrm{FeCl}_{3}, \mathrm{CuSO}_{4}$, and $\mathrm{Fe}_{2}\left(\mathrm{SO}_{4}\right)_{3}$ in Aqueous Solutions. Mater. Trans. JIM 1990, 31, 1065-1071. [CrossRef]

32. Zhao, H.; Chang, J.; Boika, A.; Bard, A.J. Electrochemistry of High Concentration Copper Chloride Complexes. Anal. Chem. 2013, 85, 7696-7703. [CrossRef]

33. Saveant, J.-M. Elements of Molecular and Biomolecular Electrochemistry; John Wiley \& Sons: Hoboken, NJ, USA, 2006.

34. Bard, A.J.; Faulkner, L.R. Electrochemical Methods, 2nd ed.; Wiley: New York, NY, USA, 2001.

35. Dai, Q.; Xu, J.J.; Li, H.J.; Yi, H.B. Ion association characteristics in $\mathrm{MgCl} 2$ and $\mathrm{CaCl} 2$ aqueous solutions: A density functional theory and molecular dynamics investigation. Mol. Phys. 2015, 113, 3545-3558. [CrossRef]

36. Wang, M.; Wang, C.; Cai, H.; Li, Y.; Zhang, Q.; Yi, H. Molecular dynamics simulation study on distinctive hydration characteristics of highly coordinated calcium chloride complexes. J. Mol. Liq. 2019, 274, 261-269. [CrossRef]

37. Kusmanov, S.A.; Silkin, S.A.; Belkin, P.N. Effect of Plasma-Electrolytic Polishing on the Corrosion Resistance of Structural Steels after Their Anodic Saturation with Nitrogen, Boron, and Carbon. Russ. J. Electrochem. 2020, 56, 356-364. [CrossRef]

38. Ngamchuea, K.; Eloul, S.; Tschulik, K.; Compton, R.G. Planar diffusion to macro disc electrodes-What electrode size is required for the Cottrell and Randles-Sevcik equations to apply quantitatively? J. Solid State Electrochem. 2014, 18, 3251-3257. [CrossRef]

39. Nikolenko, M.V.; Vasylenko, K.V.; Myrhorodska, V.D.; Kostyniuk, A.; Likozar, B. Synthesis of Calcium Orthophosphates by Chemical Precipitation in Aqueous Solutions: The Effect of the Acidity, Ca/P Molar Ratio, and Temperature on the Phase Composition and Solubility of Precipitates. Processes 2020, 8, 1009. [CrossRef]

40. Zhang, N.; Zhou, Q.; Yin, X.; Zeng, D. Trace Amounts of Aqueous Copper(II) Chloride Complexes in Hypersaline Solutions: Spectrophotometric and Thermodynamic Studies. J. Solut. Chem. 2014, 43, 326-339. [CrossRef]

41. Zhang, N.; Tang, J.; Ma, Y.; Liang, M.; Zeng, D.; Hefter, G. A spectroscopic study of solvent effects on the formation of $\mathrm{Cu}(\mathrm{II})$-chloride complexes in aqueous solution. Phys. Chem. Chem. Phys. 2021, 23, 6807. [CrossRef]

42. Manahan, S.E.; Iwamoto, R.T. Chloro Complexes of Copper(II) and Copper(I) in Acetonitrile. Inorg. Chem. 1965, 4, 1409-1413. [CrossRef]

43. Miessler, G.; Tarr, D. Inorganic Chemistry. In Pearson Educational International, 3rd ed.; Prentice Hall, 2011; pp. 367-369. Available online: https:/ / hostnezt.com/cssfiles/chemistry/Inorganic\%20Chemistry\%20By\%20GARY\%20L.\%20MIESSLER.pdf (accessed on 30 November 2021).

44. Mereshchenko, A.; Olshin, P.K.; Myasnikova, O.S.; Panov, M.; Kochemirovsky, V.; Skripkin, M.; Moroz, P.; Zamkov, M.; Tarnovsky, A. Ultrafast Photochemistry of Copper(II) Monochlorocomplexes in Methanol and Acetonitrile by Broadband Deep-UV-to-Near-IR Femtosecond Transient Absorption Spectroscopy. J. Phys. Chem. A 2016, 120, 1833-1844. [CrossRef] 